\title{
KONSEP BURUH DALAM PERSPEKTIF ISLAM
}

\author{
Havis Aravik \\ Perbankan Syariah STEBIS IGM Palembang \\ Email : havis@stebisigm.ac.id
}

\begin{abstract}
ABSTRAK
Penelitian ini membahas konsep kerja dalam perspektif Islam. Pendekatan yang digunakan dalam penelitian ini adalah pendekatan normatif, menggunakan metode analisis deskriptif kualitatif yang bertujuan untuk mendeskripsikan atau menggambarkan realitas yang ada atau apa yang terjadi atau realitas sebenarnya dalam objek yang diteliti. Islam sebagai agama rahmatan lil alamen, sangat memperhatikan pekerja. Dalam lintasan sejarah, Islam datang di era penuh ketidakadilan, penindasan, ketidakadilan, dan ketidaksetaraan ekonomi, sehingga orangorang diklasifikasikan ke dalam kelompok-kelompok kecil berdasarkan suku dan suku. Struktur sosial seperti ini, yang kemudian menimbulkan stratifikasi sosial. Islam merombak berbagai sistem diskriminatif dengan menyediakan berbagai solusi alternatif termasuk di bidang tenaga kerja. Hasil penelitian menunjukkan bahwa Islam memandang buruh sebagai Anda yang harus diperlakukan sebaik mungkin oleh majikan. Kemudian instruksikan setiap majikan untuk memperlakukan pekerja dengan baik, dalam bentuk menghormati dan mempertahankan dan bersikap ramah dan menjaga dari memperlakukan pekerja secara tidak terhormat. Islam juga mewajibkan pemberi kerja untuk menyediakan beban kerja yang tidak melebihi batas kapasitas kerja. Dan kewajiban moral seorang pekerja kepada majikan adalah menghormati majikan dengan melaksanakan semua kewajiban yang telah diikat oleh majikannya.
\end{abstract}

Keywords : Buruh, Majikan, Kapitalisme, Sosialisme, Islam

\section{DASAR PEMIKIRAN}

Salah satu permasalahan fundamental dalam sebuah negara adalah masalah buruh mulai dari tindakan sewenang-wenang pengusaha, pemberian upah yang tidak layak, PHK sepihak dan lain sebagainya. Buruh menjadi objek pembahasan penting dalam disiplin ilmu ekonomi, terutama dari aliran Kapitalisme, Sosialisme maupun Islam. Dalam ilmu ekonomi, buruh dianggap sebagai sumber daya yang dimiliki manusia yang digunakan dalam proses produksi, sehingga buruh adalah input atau faktor pengeluaran atau biaya produksi. Sementara dalam Islam, faktor buruh tidak harus dianggap sebagai biaya produksi atau faktor pengeluaran, karena hal itu akan merendahkan derajat manusia sebagai wakil Allah di atas bumi. Seorang buruh yang menjual tenaganya untuk mendapatkan imbalan upah, sejatinya dia menjual sebagaian dari apa yang dimilikinya, dan bukan menjual dirinya. Maka tidak semestinya buruh dianggap sebagai faktor produksi atau biaya pengeluaran. 
Berangkat dari permasalahan di atas, maka tulisan berikut ini akan membahas tentang konsep buruh dalam perspektif Islam. Sebagai ajaran komprehensif dan universal, agama Islam mengatur berbagai berbagai komponen dalam kehidupan manusia termasuk dalam bidang perburuhan. Dengan tujuan, agar pengetahuan tentang buruh dalam Islam tersebut, dapat terimplementasi dengan baik dalam kehidupan sehari-hari dan memberikan solusi atas berbagai permasalahan-permasalahan fundamental relasi buruh dan majikan dalam kehidupan kontemporer.

\section{PEMAHAMAN}

\section{Pengertian Buruh}

Menurut Kamus besar Bahasa Indonesia, buruh dapat diartikan dengan seseorang yang bekerja untuk orang lain yang mempunyai suatu usaha kemudian mendapatkan upah atau imbalan sesuai dengan kesepakatan sebelumnya. Upah biasanya diberikan secara harian maupun bulanan tergantung dari hasil kesepakatan yang telah disetujui. Buruh terdiri dari berbagai macam, yaitu: Buruh harian, Buruh kasar, Buruh musiman, Buruh pabrik, Buruh tambang, Buruh tani, Buruh terampil, Buruh terlatih (Abha, 2013: 20). Batasan istilah buruh/pekerja diatur secara jelas dalam UU Nomor 13 Tahun 2003 Pasal 1 angka 2 Tentang Ketenagakerjaan yang berbunyi: "Pekerja/buruh adalah setiap orang yang bekerja dengan menerima upah atau imbalan dalam bentuk lain" (Riyadi, 2015: 161).

Jadi dari berbagai pengertian di atas dapat dipahami bahwa buruh merupakan orang yang bekerja dan mendapatkan upah (gaji) atau imbalan sesuai dengan kesepakatan sebelumnya, baik secara harian, mingguan maupun bulanan, beserta kompensasi-kompensasi lainnya yang melekat padanya.

\section{Buruh dalam Perspektif Islam}

Islam sebagai agama rahmatan lil alamien, sangat memperhatikan buruh. Dalam lintasan sejarah, Islam datang pada suatu zaman yang penuh dengan kezaliman, penindasan, ketidakadilan, dan ketmpangan ekonomi, sehingga masyarakat di golongkan ke dalam kelompok-kelompok kecil berbasis suku dan kabilah. Sturktur sosial seperti inilah yang kemudian memunculkan stratifikasi sosial yang sangat kuat (Harahap, dkk, 2015: 71). 
Sistem ekonomi Islam berangkat dari kesadaran tentang etika, sebuah ethical economy. Sangat berbeda dengan sistem lain, baik kapitalisme maupun sosialisme. Kapitalisme melihat buruh hanyalah pekerja dan si majikan adalah pemberi kerja, status di antara keduanya secara otomatis menimbulkan adanya tingkatan kelas secara ke atas dan ke bawah, atau yang biasa disebut dengan stratifikasi sosial. Hal ini menimbulkan perbedaan distribusi wewenang antara majikan dan buruh serta munculnya perbedaan berdasarkan posisi, status dan kelebihan yang dimiliki. Sedangkan dalam konteks upah terhadap buruh Kapitalisme melihat bahwa pemberian upah oleh kapitalis hanya sekedar pengganti biaya atas apa yang telah dikerjakan, atau hanya sekedar untuk melanjutkan hidup serta besaran upah disesuaikan dengan standar hidup minimum di daerah tempat si buruh bekerja (Riyadi, 2015: 164).

Sedangkan dalam pandangan Sosialisme buruh merupakan pihak yang sangat tereksploitasi oleh sistem kapitalisme. Untuk itu, perlu dihilangkannya kepemilikan individu atas alat-alat produksi dan meminta peran pemerintah sebagai pelaksana perekonomian. Adapun Islam melihat buruh merupakan makhluk Allah SAW yang sama dengan manusia lainnya. Maka Islam tidak pernah menganjurkan memusuhi kekayaan dan orang-orang kaya sabagaimana dalam faham Sosialisme. Tidak juga membebaskan sebebas-bebasnya individu sebagaimana dalam faham Kapitalisme. Bahkan Islam sendiri menganjurkan agar setiap orang menjadi kaya sebagai bagian dari kebahagiaan yang harus dicapainya di dunia. Ekonomi Islam memilih jalan keadilan dalam mencapai kesejahteraan sosial. Bahwa kesejahteraan sosial yang tercapai haruslah dibangun di atas landasan keadilan (Riyadi, 2015: 168).

Berikut ini adalah beberapa konsep buruh dalam perspektif Islam, akan diuraikan sebagai dibawah ini:

1. Buruh adalah Saudara

Buruh sebagai manusia memiliki kehormatan asasi yang langsung diberikan oleh Allah. Jika buruh dianggap sebagai alat produksi sebagaimana yang terjadi dalam sistem ekonomi kapitalis maka dalam hal ini kehormatan manusia sudah disamakan dengan mesin-mesin produksi lainnya yang akan berimbas pada pengerukan keuntungan sebesar-besarnya oleh sebuah perusahaan dengan tanpa memperhatikan manusia buruh 
tersebut karena mereka dalam hal ini sudah dianggap sebagai alat produksi. Untuk itu, Islam menolak dengan tegas konsep tersebut, dan Islam membangun struktur sosial di mana setiap individu di satukan oleh hubungan persaudaran dan rasa sayang sebagaimana satu keluarga yang diciptakan oleh Allah dari sepasang manusia.

Persaudaraan ini bersifat universal, tidak terikat ruang dan batas-batas geografis tertentu serta mencakup semua umat manusia bukan hanya keluarga, suku, atau ras tertentu (QS. al-A'raf [7]: 158) (Harahap, dkk, 2015: 72). Rasulullah SAW bersabda: "Para perkerja adalah saudaramu yang dikuasakan Allah kepadamu. Maka barang siapa mempunyai pekerja hendaklah diberi makanan sebagaimana yang ia makan, diberi pakaian sebagaimana yang ia pakai, dan jangan dipaksa melakukan sesuatu yang ia tidak mampu. Jika terpaksa, ia harus dibantu" (HR. Ahmad).

Islam meletakkan dasar-dasar hubungan antara majikan dan buruh. Buruh dan majikan berda dalam level 'kemanusiaan' yang sama dalam Islam. Tidak ada yang berada di tempak lebih tinggi, meskipun dalam struktur perusahaan jelas-jelas ada kelompok pemilik modal, pemilik saham, pekerja dan lain sebagainya. Maka hubungan majikan dan buruh adalah hubungan kekeluargaan, kemitraan dan simbiosis mutualisme. Maka dari itu, tidak boleh satu pihak mendzalimi dan merasa didzalimi oleh pihak lainnya. Keduanya saling membutuhkan dan diantaranya harus tercipta saling menguntungkan. Apalagi manusia dalam masyarakat disatukan bukan untuk saling memenuhi kebutuhan satu sama lain, yang berarti mementingkan dirinya sendiri, melainkan untuk saling memelihara satu sama lain dan bertanggung jawab atas kesejahteraan seluruhnya.

\section{Perintah Memperlakukan Buruh dengan Baik}

Tidak bisa dipungkiri bahwa Islam sangat menjunjung tinggi kehormatan masing-masing individu. Sehingga dalam persoalan pekerjaan juga tidak bisa dibenarkan jika seorang majikan menjadikan buruh atau pegawainya sebagai manusia yang kurang terhormat. Islam sangat concern terhadap buruh. Buruh mendapat tempat yang sangat tinggi sebagai seorang pekerja sebagaimana seorang majikan juga bekerja dengan mempekerjakannya (Abha, 2013: 22). Maka, Islam mewajibkan untuk menciptakan suasana kekuargaan antara majikan dan buruh (QS. Al-Hujurat [49]: 10). 
Islam mengajarkan setiap majikan untuk membuang sifat keras hati dan kejam kepada buruh. Dalam hadis qudsi dari Abu Hurairah r.a, Nabi Muhammad SAW meriwayatkan: “Ada tiga orang, yang akan menjadi musuh-Ku pada hari kiamat: ... orang yang mempekerjakan seorang buruh, si buruh memenuhi tugasnya, namun dia tidak memberikan upahnya (yang sesuai).” (HR. Bukhari dan Ibn Majah). Tujuan akhir kehidupan manusia dalam Islam yaitu mencapai falah (kemenangan) dan sa'adah (kebahagiaan) di dunia dan akhirat. Oleh karena itu, baik majikan maupun buruh harus senantiasa bertakwa kepada Allah. Perasaan takwa merupakan tali pengikat antara kedua belah pihak yang akan melahirkan sifat belas kasihan, adil, jujur, dan amanah (Harahap, dkk, 2015: 77). Selain itu, Islam memotivasi agar para majikan dalam hubungan kerja bersikap tawadhu dan berwibawa dengan buruh, pembantunya. Dari Abu Hurairah, Nabi Muhammad SAW bersabda: "Bukan orang yang sombong, majikan yang makan bersama budaknya, mau mengendarai himar (kendaraan kelas bawah) di pasar, mau mengikat kambing dan memerah susunya." (HR. Bukhari).

\section{Pemberian Beban Kerja Tidak Boleh Melebihi Kemampuan}

Islam mengharuskan manusia untuk bekerja (QS. At-Taubah [9]: 105, Al-An'am [6]: 135, Hud [11]: 36, 121, dan Az-Zumar [39]: 39), dengan tujuan untuk mendapatkan upah (Qs. At-Thalaq [65]: 6, Az-Zukhruf [43]: 32). Di samping itu, sebagai makhluk sosial, di tuntut untuk selalu bekerja dalam rangka untuk memenuhi kebutuhan hidupnya, disamping untuk mengelola sumber daya alam serta mengelolanya dengan baik dalam rangka mengimplementasikan tugas khalifah di satu sisi dan abdullah di sisi lainnya (Assagaf, 2005: 13). Bekerja juga merupakan perwujudan diri manusia, melalui kerja manusia merealisasikan dirinya sebagai manusia dan sekaligus membangun hidup dan lingkungannyayang lebih manusiawi, melalui kerja manusia menjadi manusia, melalui kerja manusia menemukan hidupnya sendiri sebagai manusia yang mandiri (Sundary, 2010: 179).

Salah satu ajaran Islam mengenai buruh adalah pemberian beban kerja tidak melebihi kemampuan buruh. Al-Qur'an melalui kisah Nabi Musa, a.s. yang bekerja di rumah Nabi Syu'aib, a.s. (QS. al-Qashash [28]: 27) menunjukkan dalam pemberian kerja majikan tidak boleh mengabaikan prinsip-prinsip kemanusiaan, keadilan, dan kesamaan (Harahap, dkk, 2015: 78). Islam juga memberikan aturan yang jelas dalam hal 
transaksi kontrak kerja, dimana Islam memberikan hukum-hukum yang harus diperhatikan majian untuk memberikan perlindungan terhadap buruh.

Perlindungan tersebut menyangkut; (1) Perlindungan terhadap pekerja dan waktu istirahat yang layak (HR. al-Baihaqy); (2) Jaminan penghidupan bagi pekerja (HR. al-Nasai); (3) Menyegerakan membayar gaji (upah) (HR. Abu Dawud). Maka, termasuk kedzaliman pengusaha terhadap pekerja adalah tindakan mereka yang tidak membayar upah pekerja dengan baik, memaksa pekerja bekerja diluar kontrak kerja yang disepakati, melakukan pemutusan hubungan kerja secara semena-mena termasuk tidak memberikan hak-hak pekerja seperti hak untuk dapat menjalankan kewajiban ibadah, hak untuk istirahat jika dia sakit, dan lain sebagainya (Satjipto, 2003: 442). Bahkan al-Qur'an surah al-An'am [6]: 145 mengumpamakan majikan yang memperkerjakan buruh diluar kemampuannya seperti memeras keringatnya, menjadikanmnya sebagai mesin penggerak yang menghasilkan produk perusahaan sebagai memakan darah yang mengalir.

\section{Upah yang Layak dan Tepat Waktu}

Dalam teori ekonomi, upah secara umum dimaknai sebagai harga yang dibayarkan kepada pekerja atas jasanya dalam produksi kekayaan seperti faktor produksi lainnya. Dalam konteks kekinian pengupahan konvensional pada dasarnya dibedakan menjadi dua teori ekstrim, yaitu (1) berdasarkan ajaran Karl Marx mengenai teori nilai dan pertentangan kelas, dan (2) berdasarkan pada pertambahan produksi marginal berdasarkan asumsi perekonomian bebas. Sistem pengupahan pertama pada umumnya dilaksanakan di negara penganut paham sosialis, sedangkan sistem pengupahan kedua banyak dipakai di negara berpaham kapitalis (Syakur, 2015: 2).

Upah dalam Islam sering disebut dengan istilah jaza' (balasan atau pahala) sebagaimana sering dijumpai dalam firman Allah diantaranya surah An-Nahl [16]: 97. Kata "walanajziyannahum" pada ayat tersebut memberikan pengertian bahwa bagi mereka yang bekerja akan mendapatkan imbalan baik di dunia (materi) maupun di akhirat (pahala). Ini menegaskan bahwa Allah akan memberikan balasan atau imbalan bagi mereka baik laki-laki maupun perempuan yang beramal saleh dengan imbalan di dunia dan di akhirat (Waliam, 2017: 267). 
Islam memandang bahwa upah tidak sebatas imbalan yang diberikan kepada buruh, melainkan terdapat nilai-nilai moralitas yang merujuk pada konsep kemanusiaan. Majikan dalam menetapkan upah tidak melakukan kezaliman terhadap buruh ataupun dizalimi oleh buruh (QS. al-Baqarah [2]: 279). Dengan kata lain, majikan tidak dibenarkan mengeksploitasi buruh dan buruh tidak boleh mengeksploitasi majikannya (Harahap, dkk, 2015: 82). Oleh karena itu, agar tidak terjadi diskriminasi terhadap buruh, Islam mengatur masalah perburuah tersebut dalam sebuah hukum-hukum kontrak kerja (ijarah). Dalam transaksi ijarah terdapat dua pihak yang terlibat yakni pihak yang memberikan jasa dan mendapatkan upah atas jasa yang diberikan yang disebut dengan pekerja (ajir) dan pihak penerima jasa atau pemberi pekerjaan yakni pihak yang memberikan upah yang disebut dengan pengusaha/majikan (musta'jir) (Satjipto, 2003: 440).

Islam menganjurkan agar setiap terjadinya akad (kontrak kerja) harus dilakukan pencatatan, baik terkait dengan waktu, bentuk pekerjaan, jumlah upah yang akan diterima dan sebagainya sehingga akan terhindar dari perselisihan yang kemungkinan terjadi dikemudian hari. Upah dalam Islam dibangun atas dasar konsep keadilan atau prinsip kebersamaan untuk semua, sehingga semua pihak memperoleh bagian yang sah dari produk bersamanya tanpa adanya sikap zalim terhadap yang lain (Waliam, 2017: 271). Penetapan upah sesuai dengan kualitas kerja adalah berdasarkan kepada prinsip bahwa manusia diciptakan dengan kemampuan dan keahlian yang berbeda-beda (QS. An-Nisa [4]: 6, 32). Maka secara teori upah yang adil adalah upah yang sepadan dengan pekerjaan yang dilakukannya, dengan tetap mempertimbangkan situasi dan faktor-faktor yang terkait lainnya, tanpa perlakuan zalim baik kepada pekerja maupun kepada majikan (Harahap, dkk, 2015: 82).

Untuk itu, anjuran Islam bahwa sebelum seorang ajir memulai pekerjaan diharuskan sudah terjadi kesepakatan tentang upah yang akan diterimanya, baik terkait dengan besaran, waktu dan tempat penyerahannya. Besaran upah yang telah dinyatakan dalam transaksi tersebut dikenal dengan ajru al-musamma (upah sepadan) yang ditetapkan atas dasar kesepakatan dan kerelaan kedua belah pihak. Dengan telah disetujuinya upah dan perkara lainnya dalam akad, maka secara syar'i seorang pekerja terikat dengan akad tersebut, sehingga tidak diperbolehkan menuntut untuk 
$8 \mid$ Havis Aravik Konsep Buruh dalam Perspektif Islam

mendapatkan kenaikan upah atau hal-hal lain yang menyalahi kontrak kerja (akad) (Waliam, 2017: 272).

Selain itu, kadar upah buruh dianggap adil apabila sesuai dengan kualitas dan kuantitas bidang kerja dan sudah semestinya upah bisa mencukupi tahap minimum keperluan asas setiap manusia di suatu daerah tertentu. Hal tersebut paralel dengan Firman Allah yang mengatakan : "Dan bagi masing-masing mereka memperoleh derajat sesuai dengan apa yang telah mereka kerjakan" (Q.S Al-Ahqaf [46]: 9). Sebagaimana dilakukan Nabi Muhammad SAW : "Anas berkata bahwa Nabi Muhammad SAW. pernah melakukan bekam dan tidak sekali-kali beliau mendzalimi seseorang atas upahnya (H.R. al-Bukhari).

Selanjutnya, seorang buruh harus mendapatkan gaji setelah selesai pekerjaan. Dengan kata lain, pembayaran gaji harus dilakukan tepat waktu. Imam Abdurrahman Al-Munawi pernah mengatakan bahwa tidak diperbolehkan seseorang menunda pemberian gaji tepat waktu dengan tanpa alasan. Sebagaimana dinyatakan Rasulullah SAW bahwa "berikanlah upah sebelum keringat si pekerja kering" (Abha, 2013: 24-27). Begitu juga dalam kenaikan upah dimana upah bisa meningkat (naik) dengan bertambahnya umur pekerja dan meningkatnya pengalaman, juga ketika harga barang di pasaran melonjak, dan perusahaan mendapatkan laba yang meningkat (Rahmi, 2014: 28).

\section{Kewajiban Buruh Terhadap Majikan}

Sebagai wujud komitmen Islam terhadap keadilan, maka Islam juga melindungi majikan dengan memberikan kewajiban moral kepada para pekerja atau buruh. Nabi Muhammad SAW bersabda: “Tidak masuk Surga orang pelit, penipu, pengkhianat, dan orang yang jelek pelayananannya terhadap majikan. Sedangkan orang yang pertama kali mengetuk pintu Surga adalah para buruh yang baik terhadap sesamanya, taat kepada Allah, dan kepada majikannya." (HR. Ahmad).

Menurut Baqir Sharief Qorashi (2007: 10) dalam konteks ini Islam kewajiban kepada setiap buruh terhadap majikan antara lain : Pertama, bertanggung jawab terhadap upah yang diminta sesuai dengan pekerjaan dan kemampuannya. Dalam hal besar kecilnya upah, Islam mengakui kemungkinan terjadinya dikarenakan beberapa sebab; perbedaan jenis pekerjaan, perbedaan kemampuan, keahlian, dan pendidikan. 
Pengakuan perbedaan ini didasarkan pada firman Allah Swt, yang artinya "Apakah mereka yang membagi-bagi rahmat Tuhanmu? Kami telah menentukan antara mereka penghidupan mereka dalam kehidupan dunia, dan Kami telah meninggikan sebahagian mereka atas sebagian yang lain beberapa derajat, agar sebagian mereka dapat mempergunakan sebagian yang lain. dan rahmat Tuhanmu lebih baik dari apa yang mereka kumpulkan". (QS. al-Zukhruf [43]: 32).

Kedua, kesungguhan melaksanakan pekerjaanya, berdasarkan kontrak kerja. Ketiga, melaksanakan perintah majikan sesuai dengan pekerjaan yang telah disepakti. Apabila majikan melakukan penyimpangan terhadap kesepakatan kontrak kerja buruh tidak wajib mengikutinya dan; Keempat, menjaga dan memelihara perlengkapan dan peralatan-peralatan dan rahasia majikan (perusahaan).

\section{SIMPULAN}

Berdasarkan paparan di atas dapat disimpulkan bahwa Islam sebagai agama rahmatan lil alamien, sangat memperhatikan buruh. Islam melihat buruh merupakan makhluk Allah SAW yang sama dengan manusia lainnya. Maka Islam tidak pernah menganjurkan memusuhi kekayaan dan orang-orang kaya sabagaimana dalam faham Sosialisme. Tidak juga membebaskan sebebas-bebasnya individu sebagaimana dalam faham Kapitalisme. Untuk itu, Islam memandang buruh adalah Saudara yang harus diperlakukan sebaik mungkin oleh majikan. Kemudian memerintahkan setiap majikan untuk memperlakukan buruh dengan baik, dalam bentuk menghormati dan menjaga serta bersikap ramah dan menjaga dari memperlakukan buruh secara tidak terhormat.

Islam juga mengharuskan majikan untuk memberikan beban kerja yang tidak melebihi batas kemampuan buruh. Hal ini dilukiskan dalam Al-Qur'an melalui kisah Nabi Musa a.s, yang bekerja di rumah Nabi Syu'aib, a.s. (QS. al-Qashash [28]: 27), serta memberikan upah yang layak dan tepat waktu kepada buruh. Sedangkan kewajiban moral seorang buruh terhadap majikan Islam memberikan tuntunan agar setiap buruh menghormati majikan dengan cara melaksanakan segala kewajiban yang telah terikat dengan majikannya. 


\section{Daftar Pustaka}

Harahap, Isnaini, dkk, 2015. Hadis-Hadis Ekonomi, Jakarta: Kencana Prenada Media Group.

Syakur, Ahmad, 2015. "Standar Pengupahan dalam Ekonomi Islam; Studi Kritis atas Pemikiran Hizbut Tahrir”, Universum, Vol. 9 No. 1 Januari 2015.

Abha, Muhammad Makmum, 2013. "Teologi Upah Dan Kesejahteraan Buruh dalam Perspektif Hadis”, Jurnal Syari'ah, Vol. II, No. II, Oktober 2013.

Satjipto, Hadi, 2003. "Solusi Islam Terhadap Masalah Ketenagakerjaan", Mimbar; Jurnal Sosial dan Pembangunan, Volume 19, No. 4, Tahun 2003.

Assagaf, Yunus, 2005. "Ketatanegaraan dalam Konsepsi Syariat Islam”, Al-Syir'ah, Vol. 3, No. 1, 2005.

Sundary, Rini Irianti, 2010. Internalisasi Prinsip-Prinsip Islam Tentang Etika Kerja dalam Perlindungan Hak Pekerja dan Pelaksanaan Hak Atas Pekerjaan", Syiar Hukum, Vol. XII. No. 2 Juli 2010.

Rahmi, Aini, 2014. " Tanggung Jawab Perusahaan dan Karyawan dalam Islam”, alMaslahah; Jurnal Ilmu Syariah, Vol. 9, No. 2, 2014.

Waliam, Armansyah, 2017. "Upah Berkeadilan Ditinjau dari Perspektif Islam", Bisnis, Vol. 5, No. 2, Desember 2017.

Riyadi, Fuad, 2015. "Sistem dan Strategi Pengupahan Perspektif Islam”, Iqtishadia, Vol 8, No. 1, Maret 2015.

Qorashi, Baqir Sharief, 2007. Keringat Buruh, Hak dan Peran Pekerja dalam Islam, Jakarta: Penerbit Al-Huda. 